\title{
The Role of Inclusion in Climate Vulnerability Assessment and Equitable Adaptation Goals in Small American Municipalities
}

Elena Lioubimtseva ( $\sim$ lioubime@gvsu.edu )

Grand Valley State University

\section{Research Article}

Keywords: vulnerability, exposure, sensitivity, adaptive capacity, inclusion, diversity, equity, small city, stakeholder, planning, United States

Posted Date: November 16th, 2021

DOl: https://doi.org/10.21203/rs.3.rs-1075793/v1

License: (9) (1) This work is licensed under a Creative Commons Attribution 4.0 International License. Read Full License

Version of Record: A version of this preprint was published at Discover Sustainability on January 20th, 2022. See the published version at https://doi.org/10.1007/s43621-022-00071-0. 


\section{Abstract}

Equity and inclusion considerations are important prerequisites of effective climate adaptation planning, especially at a local scale. This pilot study examines how climate adaptation plans of small American cities and counties consider equity in their climate vulnerability assessments and adaptation planning goals, and how consideration of equity in existing adaptation plans relates to inclusion of diverse categories of stakeholders. Data analysis is based on the content of 23 local climate adaptation plans of small urban and rural municipalities across the United States with population less than 300 thousand people. Correlations between conceptualization of vulnerability dimensions, inclusion of 9 categories of stakeholders, and consideration of equity in 12 different domains of adaptation planning are examined. The study concludes that municipalities, who examine their vulnerability beyond physical exposure to climate impacts and consider sensitivity and adaptive capacity of their populations, appear to be more attentive to social equity and more likely to offer specific adaptation measures focusing on vulnerable groups.

\section{Introduction}

Climate change adaptation planning seeks to adjust human-environmental systems in response to actual or expected climatic stimuli to minimize their harms or exploit beneficial opportunities (IPCC WGII, 2014). Reducing human vulnerability to current and future climate change impacts is essential and many cities in the United States and worldwide have developed climate adaptation plans during the past decade (Bierbaum, et al., 2013;Woodruff \& Stults, 2016; Lioubimtseva \& da Cunha, 2020).

Climate adaptation planning efforts in the United States have been driven bottom-up by the state, local, and tribal initiatives (Bierbaum et al., 2013; Vogel et al., 2016), are developed with using a wide range of methodologies, and their presence and level of coordination vary across different states (Lioubimtseva \& da Cunha, 2020). Due to the absence of uniform planning guidelines and vast variety of priorities, the majority of climate adaptation plans have no clearly defined social and environmental equity standards. As a consequence, it is unclear if the existing plans reflect the needs of all residents or only more influential groups, possibly not reducing or even disproportionally increasing vulnerability of others (Olazabal et al. 2019). It is also not known if community members and organizations representing interests of marginalized groups have anything to contribute to the public understanding of human vulnerability and appropriate adaptation planning targets and strategies (Thomas \& Twyman, 2005).

Low income people, elderly, infants, homeless, displaced, and other vulnerable populations are disproportionally affected by impacts of climate change impacts, such as heat waves, floods, wildfires, and other disasters, vector-and water-borne (International Housing Coalition, 2011; Reckien et al., 2018). People of color, indigenous and immigrant communities, and other minority groups often face critical barriers to involvement in community planning due to historical disenfranchisement and have less resources for adaptions (Anguelovski, et al., 2016).

Scholarly literature on local climate adaptation planning is still emerging and most research has been dedicated to the experience of larger high-capacity cities (Araos, et al., 2016; Woodruff, 2018). Although the number of local climate adaptation plans developed by communities of all sizes and scales continues to grow in the United States response to increasing threats of climate, very few studies have addressed the experience of small and mid-size towns and cities. Small cities, towns, and villages provide a home for a very large part of the population but have received limited attention in the climate adaptation literature, which has been largely focused on big cities (Lioubimtseva \& da Cunha, 2020). Small municipalities have fewer resources, less access to national and international networks, and limited opportunities for peer learning, being excluded from the global and national adaptation networks (Lioubimtseva and da Cunha, 2020). And because local climate adaptation planning is not mandatory in the United States, only a handful of small cities and counties have developed climate adaptation plans to date. This study examines the role of stakeholders' inclusion in climate vulnerability assessment and equitable adaptation goals in small cities, towns, and counties. This inquiry is driven by the three related hypotheses:

- Consideration of equity in climate adaptation goals depends on how vulnerability is assessed by a community and if the latter includes socioeconomic and demographic factors of its sensitivity and adaptive capacity. 
- The scope of vulnerability assessment is influenced by and correlates with inclusion of diverse groups of stakeholders involved in climate adaptation planning.

- Consideration of equity in climate adaptation planning goals is influenced by and correlates with inclusion of diverse groups of stakeholders involved in climate adaptation planning.

\section{Methodology}

\subsection{Local climate adaptation plans}

The dataset generated for this study consists of 23 climate adaptation plans of small urban and rural municipalities across the United States with population less than 300 thousand people (Figure 1). The search of climate adaptation plans was informed by the Georgetown Climate Center Adaptation Clearinghouse database (Georgetown Climate Center, 2021), scholarly reviews of existing local adaptation plans (Bierbaum et al., 2013; Vogel et al., 2016; Woodruff \& Stults, 2016, and da Cunha \& Lioubimtseva, 2021), Internet searches, and information requests to the jurisdictions identified through the searches. Only 23 municipalities with population less than 300 thousand people with publicly available local climate adaptation plans have been found across the country (Figure 1). These cities and counties are listed in Table 1, with a summary of climate change impacts addressed in their climate adaptation plans. 
Table 1

Local climate adaptation plans examined in this study.

\begin{tabular}{|c|c|c|c|c|c|c|c|c|c|}
\hline \multirow[t]{2}{*}{ Municipality } & \multirow[t]{2}{*}{ Source } & \multicolumn{8}{|c|}{ Impacts of climate change addressed } \\
\hline & & $\begin{array}{l}\text { Shoreline } \\
\text { changes }\end{array}$ & $\begin{array}{l}\text { Severe } \\
\text { storms }\end{array}$ & $\begin{array}{l}\text { Extreme } \\
\text { heat }\end{array}$ & $\begin{array}{l}\text { Extreme } \\
\text { cold }\end{array}$ & Flooding & Drought & Wildfires & $\begin{array}{l}\text { Seasonal } \\
\text { shifts }\end{array}$ \\
\hline Albany, NY & $\begin{array}{l}\text { (New York } \\
\text { State } \\
\text { Department } \\
\text { of State, } \\
2013 \text { ) }\end{array}$ & & $x$ & $x$ & $x$ & $x$ & & & $x$ \\
\hline $\begin{array}{l}\text { Boulder } \\
\text { County, CO }\end{array}$ & $\begin{array}{l}\text { (Stratus } \\
\text { Consulting, } \\
\text { 2012) }\end{array}$ & & & $x$ & $x$ & $x$ & $x$ & $x$ & \\
\hline $\begin{array}{l}\text { Alger } \\
\text { County, MI }\end{array}$ & $\begin{array}{l}\text { (Klipp, Thaler, } \\
\text { Griffith, \& } \\
\text { Crossett, } \\
\text { 2011) }\end{array}$ & $x$ & $x$ & $x$ & $x$ & $x$ & $x$ & $x$ & $x$ \\
\hline $\begin{array}{l}\text { Chula Vista, } \\
\text { CA }\end{array}$ & $\begin{array}{l}\text { (City of Chula } \\
\text { Vista, 2011) }\end{array}$ & $x$ & $x$ & $x$ & & $x$ & $x$ & $x$ & \\
\hline $\begin{array}{l}\text { Corte } \\
\text { Madera, CA }\end{array}$ & $\begin{array}{l}\text { (Town of } \\
\text { Corte } \\
\text { Madera, } \\
\text { 2021) }\end{array}$ & $x$ & $\mathrm{x}$ & $x$ & & $x$ & $\mathrm{x}$ & $\mathrm{x}$ & \\
\hline $\begin{array}{l}\text { Flagstaff, } \\
\text { AZ }\end{array}$ & $\begin{array}{l}\text { (City of } \\
\text { Flagstaff, } \\
\text { 2012); (City } \\
\text { of Flagstaff, } \\
\text { 2018) }\end{array}$ & & $x$ & $x$ & & $x$ & $x$ & $x$ & $x$ \\
\hline $\begin{array}{l}\text { Georgetown, } \\
\text { ME }\end{array}$ & $\begin{array}{l}\text { (Georgetown } \\
\text { Conservation } \\
\text { Commission, } \\
2015 \text { ) }\end{array}$ & $x$ & $x$ & & & $x$ & & & \\
\hline Groton, CT & $\begin{array}{l}\text { (Stults \& } \\
\text { Pagach, } \\
\text { 2011) }\end{array}$ & $x$ & $\mathrm{x}$ & $x$ & & $x$ & $\mathrm{X}$ & & $x$ \\
\hline lowa City, IA & $\begin{array}{l}\text { (City of lowa } \\
\text { City, 2018) }\end{array}$ & & $x$ & $x$ & & $x$ & $x$ & & $x$ \\
\hline Keene, NH & $\begin{array}{l}\text { (City of } \\
\text { Keene, 2007); } \\
\text { (City of } \\
\text { Keene, 2010) }\end{array}$ & & $x$ & $x$ & $x$ & $x$ & $x$ & & $x$ \\
\hline $\begin{array}{l}\text { Laguna } \\
\text { Woods, CA }\end{array}$ & $\begin{array}{l}\text { (City of } \\
\text { Laguna } \\
\text { Woods City } \\
\text { Council, } \\
\text { 2014) }\end{array}$ & & $x$ & $x$ & & $x$ & $x$ & $x$ & \\
\hline $\begin{array}{l}\text { Marquette, } \\
\text { MI }\end{array}$ & $\begin{array}{l}\text { (Michigan } \\
\text { State } \\
\text { University, } \\
\text { 2013) }\end{array}$ & $x$ & $x$ & $x$ & & $x$ & $x$ & & $x$ \\
\hline $\begin{array}{l}\text { Marquette } \\
\text { County, MI }\end{array}$ & $\begin{array}{l}\text { (King, et al., } \\
\text { 2013) }\end{array}$ & $x$ & $x$ & $x$ & $x$ & $x$ & $x$ & $x$ & $x$ \\
\hline $\begin{array}{l}\text { Marshfield, } \\
\text { MA }\end{array}$ & $\begin{array}{l}\text { (Chase, et al., } \\
\text { 2012) }\end{array}$ & $x$ & $x$ & $x$ & $x$ & $x$ & & & $x$ \\
\hline
\end{tabular}




\begin{tabular}{|c|c|c|c|c|c|c|c|c|c|}
\hline \multirow[t]{2}{*}{ Municipality } & \multirow[t]{2}{*}{ Source } & \multicolumn{8}{|c|}{ Impacts of climate change addressed } \\
\hline & & $\begin{array}{l}\text { Shoreline } \\
\text { changes }\end{array}$ & $\begin{array}{l}\text { Severe } \\
\text { storms }\end{array}$ & $\begin{array}{l}\text { Extreme } \\
\text { heat }\end{array}$ & $\begin{array}{l}\text { Extreme } \\
\text { cold }\end{array}$ & Flooding & Drought & Wildfires & $\begin{array}{l}\text { Seasonal } \\
\text { shifts }\end{array}$ \\
\hline $\begin{array}{l}\text { North } \\
\text { Kingston, RI }\end{array}$ & $\begin{array}{l}\text { (Rhode } \\
\text { Island Sea } \\
\text { Grant \& } \\
\text { University of } \\
\text { Rhode Island } \\
\text { Coastal } \\
\text { Resources } \\
\text { Center, 2015) }\end{array}$ & $x$ & $x$ & $x$ & $\mathrm{x}$ & $\mathrm{X}$ & & & $\mathrm{x}$ \\
\hline $\begin{array}{l}\text { Punta } \\
\text { Gorda, FL }\end{array}$ & $\begin{array}{l}\text { (Beever III, et } \\
\text { al., 2009); } \\
\text { (Taylor } \\
\text { Engineering, } \\
\text { 2019) }\end{array}$ & $x$ & $x$ & $x$ & & $x$ & & & \\
\hline Salem, MA & $\begin{array}{l}\text { (City of } \\
\text { Salem } \\
\text { Department } \\
\text { of Planning \& } \\
\text { Community } \\
\text { Development, } \\
\text { 2014) }\end{array}$ & $x$ & $x$ & $x$ & & $x$ & & & \\
\hline $\begin{array}{l}\text { Santa Cruz, } \\
\text { CA }\end{array}$ & $\begin{array}{l}\text { (City of } \\
\text { Santa Cruz, } \\
\text { 2011); (City } \\
\text { of Santa } \\
\text { Cruz Climate } \\
\text { Action } \\
\text { Program, } \\
\text { 2018) }\end{array}$ & $x$ & $x$ & $x$ & & $x$ & $x$ & $x$ & \\
\hline $\begin{array}{l}\text { Sarasota, } \\
\text { FL }\end{array}$ & $\begin{array}{l}\text { (City of } \\
\text { Sarasota, } \\
\text { 2016); (City } \\
\text { of Sarasota, } \\
\text { 2017) }\end{array}$ & $x$ & $x$ & $x$ & & $x$ & & & \\
\hline $\begin{array}{l}\text { Taos } \\
\text { County, NM }\end{array}$ & $\begin{array}{l}\text { (Foster, } \\
\text { Williams, } \\
\text { Thaler, \& } \\
\text { Griffith, } \\
\text { 2010) }\end{array}$ & & $x$ & $x$ & & $x$ & $x$ & $x$ & $x$ \\
\hline $\begin{array}{l}\text { Tompkins } \\
\text { County, NY }\end{array}$ & $\begin{array}{l}\text { (Tompkinds } \\
\text { County } \\
\text { Planning } \\
\text { Department, } \\
\text { 2015) }\end{array}$ & & $x$ & $x$ & & $x$ & $x$ & & \\
\hline $\begin{array}{l}\text { Tybee } \\
\text { Island, GA }\end{array}$ & $\begin{array}{l}\text { (Evans, } \\
\text { Gambill, \& } \\
\text { McDowell, } \\
\text { 2013) }\end{array}$ & $x$ & $x$ & & & $x$ & & & \\
\hline $\begin{array}{l}\text { Watsonville, } \\
\text { CA }\end{array}$ & $\begin{array}{l}\text { (Harris \& } \\
\text { Associates, } \\
\text { 2021) }\end{array}$ & $x$ & $x$ & $x$ & & $x$ & $x$ & $x$ & \\
\hline
\end{tabular}

\subsection{Analytical Framework}

This research is a pilot study exploring complex relationships among the three aspects of climate adaptation planning: a) vulnerability assessment scope, b) inclusion of stakeholders in climate adaptation planning, and c) consideration of equity in adaptation planning goals in various domains (Figure 2). 


\subsubsection{Interpretation of vulnerability}

Vulnerability to climate change impacts can be defined as "the degree, to which a system is susceptible to, or unable to cope with adverse effects of climate change, including climate variability and extremes" (IPCC 2007, p. 883), as well as "the propensity or predisposition to be adversely affected by impacts of climate change" (IPCC, 2012, p. 32). Human vulnerability is a composite variable, defined by three groups of biophysical and socioeconomic factors that constitute exposure, sensitivity and adaptive capacity (Howe et al. 2013) and can be assessed at a local scale using Vulnerability Scoping Diagram (VSD) approach (Polsky et al., 2007) as a combination of geographical, demographic, and socio-economic indicators (Table 2).

Exposure is defined by the IPCC (2007) as the nature and degree to which a system is exposed to significant climate variations. Exposure may be represented as changes in long-term climate conditions or by changes in climate variability, including the magnitude and frequency of extreme events (Monterroso \& Conde, 2015). Its spatial pattern is uneven, even at a scale of smaller municipalities. Some areas are more exposed than others to effects flooding, wildfires, heat waves, and storms due to their landforms, soils, vegetation, hydrology, and other elements of their landscape and physical geography.

Sensitivity is the degree to which a system may be affected, either adversely or beneficially, when exposed to climate variability or change or geophysical hazards (IPCC WGII, 2014). For example, sensitivity to effects of flooding, wildfires and heat waves of people living in the same place varies significantly depending on their age, gender, health, and wellness. Elderly people, pregnant women, infants, and people with health conditions and physical or mental disabilities are particularly sensitive to weather extremes.

Adaptive capacity relates to the capacity of systems, institutions, humans, and other organisms to adjust to potential damage, to take advantage of opportunities, or to respond to consequences (IPCC WGII, 2014). At the local scale it implies all community and individuals' assets available for climate adaptation, such as infrastructure, financial assets, access to infrastructure, information, technology, transportation, insurance, health care, food, and other resources. For example, consequences of exposure to the same disaster, such as a hurricane or a wildfire, depend on effectiveness of adaptation and emergency plans, evacuation and rescue operations, and ability of communities or individuals to safely relocate and restore their livelihoods. Adaptation capacity is the key factor defining adaptation planning options.

Table 2

Examples of local indicators of human vulnerability

\begin{tabular}{|c|c|c|c|}
\hline Climate impact & $\begin{array}{l}\text { Indicators of } \\
\text { exposure } \\
\text { (E) }\end{array}$ & $\begin{array}{l}\text { Indicators of } \\
\text { sensitivity } \\
\text { (S) }\end{array}$ & $\begin{array}{l}\text { Indicators of adaptive } \\
\text { capacity } \\
\text { (AC) }\end{array}$ \\
\hline $\begin{array}{l}\text { Flush flooding due to extreme } \\
\text { precipitation }\end{array}$ & $\begin{array}{l}\text { - altitude, } \\
\text { • slope, } \\
\text { • rocks, } \\
\text { • soils, } \\
\text { • hydrology, } \\
\text { - land use, } \\
\text { • area size, } \\
\text { - population density }\end{array}$ & $\begin{array}{l}\text { • age, } \\
\text { • gender, } \\
\text { • health, } \\
\text { • wellness, } \\
\text { • fitness, } \\
\text { • mobility, } \\
\text { • occupation, } \\
\text { - lifestyle, } \\
\text { - disability status }\end{array}$ & $\begin{array}{l}\text { storm infrastructure, } \\
\text { emergency services, } \\
\text { evacuation plan, } \\
\text { transportation, } \\
\text { food security, } \\
\text { health care, } \\
\text { flooding insurance, } \\
\text { funds for relocation, } \\
\text { resources to rebuild }\end{array}$ \\
\hline
\end{tabular}


Vulnerability can be best understood as a function of exposure, sensitivity and adaptive capacity: $V=f[E * S *(-A C)]$, where $V$ is vulnerability, $E$ is exposure, $S$ is sensitivity, and AC is adaptive capacity (Polsky, 2007). In theory, if all factors are considered, human vulnerability is an objective measurable variable, used to inform climate adaptation goals. Communities are encouraged to conduct their vulnerability assessment before embarking on climate adaptation planning projects ( (Brown, 2011; ICLEI Local Governments for Sustainability, 2019; (IPCC, 2012; Smit \& Wandel, 2006)), and the majority of local adaptation plans are either based on a vulnerability assessment report or include at least a section dedicated to the discussion of vulnerability. In the absence of national and state guidelines, cities are left to almost endless choice of methodologies for vulnerability assessment, ranging from community surveys to modeling scenarios developed by external firms or local universities, who also use a wide range of conceptual frameworks (Lioubimtseva \& da Cunha, 2020; da Cunha and Lioubimtseva, 2021). Vulnerability assessments provide critically important information for guiding climate adaptation goals and future performance evaluation of climate adaptation plans. In theory, they are meant to be objective. We argue, however, that in practice, local vulnerability assessments are highly subjective because they depend on how they are conducted, by whom, and with whose priorities in mind. This is why I introduce the concept of "perceived vulnerability" (PV) to differentiate it from the well-established concept of "vulnerability".

\subsubsection{Consideration of climate equity and justice}

Issues of climate equity and justice are still far more readily discussed in the scholarly literature at a country-to-country scale than at a scale of individual cities (Thomas \& Twyman, 2005) and hardly any data is available on climate equity in small municipalities (Lioubimtseva \& da Cunha, 2022). Equity can be defined as "the state, quality or ideal of being just, impartial and fair" (AECF, 2021). In the context of this study it is examined both as a process and its outcomes that relate to consideration of climate vulnerabilities and adaptation objectives. Equity is a social concept, closely related to a legal term "justice". Climate justice offers a human rights perspective on the climate crisis acknowledging that climate change has differing social, economic, public health, and other adverse impacts on underprivileged population (United Nations, 2021). Climate justice can have distributive and procedural forms (Bulkeley et al., 2013), where the former relates to the distribution of adverse impacts of climate change, and the latter to how and by whom adaptation planning decisions should be made (Thomas \& Twyman, 2005). In climate adaptation planning, equity and justice imply planning strategies to eliminate disparities and create physical and social environment, that aim to ensure a fairer distribution of community resources along race, class, gender, and other dimensions of diversity (Northridge \& Freeman, 2011). Climate change adaptation planning seeks to adjust humanenvironmental systems in response to actual or expected climatic stimuli to minimize their harms or exploit beneficial opportunities. Therefore, attention to equity and justice in climate adaptation planning is paramount to reduce vulnerability of all residents and neighborhoods. In this study we use twelve (12) domains of climate adaptation planning to assess "consideration of equity" (CE) in climate adaptation plans. These twelve adaptation domains include green and blue infrastructure, housing, energy security, transportation infrastructure and services, utility infrastructure and services, emergency services, food security, water quality, air quality, community education, insurance access, and health and wellness. Consideration of equity in each of these 12 domains is evaluated on a scale from 0 to 3 , defined as following: 0 - adaptation domain is absent; 1 - adaptation domain is present, but does not address equity; 2 - adaptation domain is present and equity is acknowledged as a value but strategies for achieving equity are not explained; 3 - adaptation domain is present and strategies for achieving equity are explained.

\subsubsection{Diversity and inclusion of stakeholders}

Diversity involves various social categories based on class, gender, occupation, income, education, race, ethnicity, age, and ability, which may have very different levels of exposure, sensitivity, and adaptive capacity to climate impacts. Observable dimensions of diversity include such characteristics as gender, race, ethnicity, and age, which are legally protected from discrimination in the United States (Roberson, 2004) but can also include many other characteristics, such as education, professional and socioeconomic background, immigration status, income, and various cultural associations (e.g. religion, ancestry, or social causes). Low income people and minorities often tend to live in more hazard-prone and crowded areas with older infrastructure (Agyeman et al., 2003), higher air and water pollution (Miranda et al., 2011), and limited access to green

Page 7/19 
spaces (Andersson et al., 2019). These circumstances increase their vulnerability to impacts of climate change and reduce their capacity to adapt to and withstand extreme event (Reckien et al., 2018). The concept of diversity is closely related to inclusion, which can be defined as the degree to which an individual perceives that he or she is an esteemed member of a group through experiencing treatment that satisfies his or her needs for belongingness and uniqueness (Shore et al., 2011). To serve the entire community, the process of developing a local adaptation plan must be inclusive (Uittenbroek et al., 2019); engaging the entire spectrum of stakeholders and especially vulnerable groups is a criterion of procedural justice (Holland, 2017). While it is difficult to capture all demographic and socioeconomic data necessary to fully evaluate diversity and inclusion of stakeholders, involvement of civil rights and urban advocacy organizations, such as National Urban League, climate justice groups, such as Climate Collaborative, Climate Justice Alliance, and Earth Justice, and local community organizations advocating for climate equity and justice can provide at least indirect insights about social inclusion.

In this study we examine nine (9) categories of stakeholders involved in design of local climate adaptation plans: residents and neighborhood associations, environmental and climate advocacy groups, social justice advocacy groups, elected members of local governments, planning departments and public utilities staff, representatives of state or federal agencies, academics, local businesses, and external environmental engineering firms hired by cities to assist with vulnerability assessment and plan writing. Their participation in climate adaptation planning is used here as a proxy measure of "inclusion of stakeholders" (IS). Stakeholders' engagement in the adaptation planning is classified on the scale from 0 to 4: none (0), participant (1), partner (2), and co-author (3), ranging from no influence to total influence, as a simplified application of "inform - consult - collaborate empower" model (International Association for Public Participation, 2018).

\subsection{Assessment}

All 23 adaptation plans are evaluated and compared based on criteria of their perceived vulnerability (PV), inclusion of stakeholders (IS) in the adaptation planning process, and consideration of equity (CE) in the proposed climate adaptation goals. Criteria for PV, IS, and CE ranking are summarized in Table 3. These criteria are not weighted, assuming that they are equally important, which is a methodological limitation of this pilot study.

Table 3

Adaptation plans assessment criteria

\begin{tabular}{|c|c|c|c|}
\hline & PV & IS & CE \\
\hline score & $\begin{array}{l}\text { Assessment of } 3 \text { dimensions of } \\
\text { vulnerability: exposure, sensitivity, and } \\
\text { adaptive capacity in overall vulnerability } \\
\text { assessment }\end{array}$ & $\begin{array}{l}\text { Engagement of each } \\
\text { of the } 9 \text { types } \\
\text { stakeholders involved } \\
\text { in planning }\end{array}$ & $\begin{array}{l}\text { Consideration of climate justice in each of } \\
\text { the } 12 \text { adaptation planning domains } \\
\text { considered. }\end{array}$ \\
\hline 0 & Absent from the assessment & $\begin{array}{l}\text { None (possibly } \\
\text { passively informed) }\end{array}$ & Adaptation domain is absent \\
\hline 1 & $\begin{array}{l}\text { Mentioned but not clearly defined or } \\
\text { assessed }\end{array}$ & $\begin{array}{l}\text { Participant (interviews, } \\
\text { surveys, public } \\
\text { meetings) }\end{array}$ & $\begin{array}{l}\text { Adaptation domain is present, but does } \\
\text { not address equity }\end{array}$ \\
\hline 2 & Defined but not assessed & $\begin{array}{l}\text { Partner (active } \\
\text { collaborator in } \\
\text { decision making) }\end{array}$ & $\begin{array}{l}\text { Adaptation domain is present and equity } \\
\text { is acknowledged as a value but strategies } \\
\text { for achieving equity are not explained }\end{array}$ \\
\hline 3 & Assessed based on clearly defined criteria & Co-author of the plan & $\begin{array}{l}\text { Adaptation domain is present and } \\
\text { strategies for achieving equity are } \\
\text { explained }\end{array}$ \\
\hline
\end{tabular}

To examine how these three variables, correlate and influence each other I evaluated them based on the content of each adaptation plan in this sample.

$\mathrm{PV}=\frac{\mathrm{E}+\mathrm{S}+\mathrm{AC}}{9} \times 100 \backslash \%$, where $\mathrm{E}$ is exposure, $\mathrm{S}$ is sensitivity, $\mathrm{AC}$ is adaptive capacity, each ranked on a scale from 0 to 3 based on the level of their assessments in the local adaptation plans. 


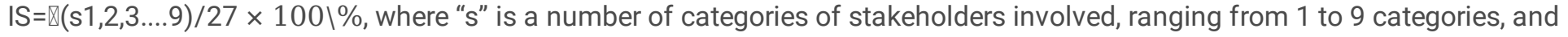
their engagement ranked on a scale $0-3$;

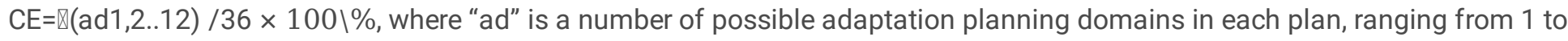
12 , with consideration of equity in each ranked on a scale from 0 to 3 .

\section{Results And Discussion}

Figures 3-6 illustrate patterns of relationships among perceived vulnerability, inclusion of stakeholders, and consideration of equity. Due to the small size of my sample, this semi-quantitative analysis should be regarded with caution and not be used for extrapolation.

First of all, it is clear that communities' PV varies significantly and magnitude of this variability is driven by the choice methodological guidelines and assessment approaches. These is because some municipalities choose to interpret vulnerability solely as a biophysical exposure to impacts, while others also consider socioeconomic aspects of sensitivity and adaptive capacity. Vulnerability assessment is an essential prerequisite of adaptation planning (Brown, 2011; IPCC, 2012; Smit \& Wandel, 2006) and is typically encouraged in the guidelines of various state, national, and international agencies ( (ICLEI Local Governments for Sustainability, 2019; California Governor's Office of Emergency Services, 2020; Institute for Local Government, 2021). In the absence of national climate adaptation standards, and state guidelines in most states, local communities define and assess their vulnerability in a variety of ways. This make the tasks of long-term monitoring and comparative analysis very problematic. As Woodruff \& Stults (2016) show, there are "numerous strategies but limited implementation guidance in local climate adaptation plans". In our sample, all 23 plans provided analysis of exposure to current and expected climate impacts, and 17 of them received the highest score (3) for providing detailed analysis based on their location and physiographic conditions. However, only 4 plans received top score (3) for their sensitivity assessments, while 10 plans did not mention any sensitivity criteria at all. Only 5 plans scored 3 based on their adaptive capacity assessments, and 7 plans omitted consideration of adaptive capacity criteria all together. Such omission of socioeconomic dimensions of vulnerability is neither unique to small cities not to the United States and has been previously noted in other comparative adaptation studies (Olazabal, Gallaraga, Ford, Sainz, \& Lesnikowski, 2019; Lioubimtseva \& da Cunha, 2022). Local plans use a very wide range of methodological and conceptual approaches, largely differing from state to state and city to city, and their interpretations of what "vulnerability" is and how it can be assessed is far from being uniform. Perhaps the most striking example of such variety of approaches in this sample is offered by the plans of the City of Marquette (Michigan State University, 2013) and Marquette County(King, et al., 2013) in Michigan. Both plans are published the same year covering overlapping geographic areas (the City of Marquette and the surrounding predominantly rural area of Marquette County, which also includes the City OF Marquette). Yet, being developed by different groups of stakeholders with assistance of different external agencies they adopted different methodological approaches, not aiming for compatibility or coordination. Overall, attention to physical exposure to climate impacts clearly prevails over socioeconomic aspects of sensitivity and adaptive capacity in the majority of climate adaptation plans under various assessment guidelines (Figure 4).

Similarly, inclusion of stakeholders varies significantly among the plans (figure 5). While local governments, planning departments, and other municipal services typically co-author most plans, engagement of residents, social and environmental advocacy groups, local businesses, and academia varies significantly from place to place. Such variability of participants could be the main reason of a very broad range of guidelines adopted by individual communities. For example, university cities benefit from involvement of local faculty and students. They are far more likely to use planning guidelines that are well informed by robust climate data and current scholarly literature and to invite climate adaptation experts to the public meetings. Collaboration with local universities promotes national and international visibility of small college towns and often brings external grants to fund vulnerability assessments and climate adaptation plans, sometimes used as case studies in larger methodological projects.

When it comes to consideration of equity in climate adaptation domains, the differences among the plans appear to be striking, with CE index ranging from $87 \%$ for Albany, NY to $11 \%$ for Georgetown, ME (Figure 6).

Page 9/19 
Pearson correlation coefficient $r$ is used to explore the relationships between PV, IS, and CE to test the initial hypotheses (p.3). There is a very strong positive correlation $(+0.57)$ between the total values of PV and CE confirming that when vulnerability assessment includes not only biophysical but also socioeconomic and demographic factors, it is conducive to consideration of equity in adaptation planning goals. A significant positive correlation also appears between IS and CE, proving true that plans developed by more inclusive groups of diverse stakeholders tend to address equity setting their climate adaptation goals. These findings agree with other studies on the role of stakeholders' engagement and public participation in successful climate adaptation planning (Aguiar et al. 2018; Elelman and Feldman 2018; Hügel \& Davis, 2020; Rivaset al., 2021). These correlations are not direct causations and may be explained by several factors calling for more in-depth research. For example, it is possible that more progressive cities and cities with demographically diverse populations, such as Albany, NY and Watsonville, CA, make more intentional efforts to address diversity, equity, and inclusion in city planning. The recency of the plan is another significant factor - with a few exceptions, climate adaptation plans produced in the past 4-5 years pay more attention to sensitivity and adaptive capacity in addition to exposure, and provide more information about equity in their adaptation goals. This is a positive sign, suggesting that cities learn from the evolving body of knowledge and improve their methodologies with time.

On the other hand, only negligible correlation was found between IS and PV. This finding agrees with a recent study by Lioubimtseva and da Cunha (2022) of French and American climate plans, suggesting that in practice stakeholders have little to contribute to the choice of vulnerability assessment methods. Guidelines and protocols for vulnerability assessments are typically written by experts and are often packaged with funding sources or training programs of their sponsoring agencies, leaving little room for change. The importance of coordinated methodologies can be further illustrated by a handful of plans from the state of California. California provides significant assistance, coordination, and technical guidelines to local governments through state-wide climate adaptation strategy and adaptation planning guides (California Natural Resources Agency \& the Governor's Office of Planning and Research, 2021). The state addressed adaptation to climate change through the California Climate Adaptation Strategy (California Natural Resources Agency \& the Governor's Office of Planning and Research, 2021) and California Adaptation Planning Guide (California Governor's Office of Emergency Services, 2020), providing a statewide decision-making framework intended for use by local and regional stakeholders. The state also produced four major assessments of local and statewide vulnerabilities to climate change in 2006, 2009, 2012, and 2018(California Environmental Protection Agency, 2021) and developed Cal-Adapt (Geospatial Innovation Facility at University of California, 2021) - a webbased platform, which enables city and county planners, government agencies, and the public to identify potential climate change risks in specific areas throughout California. Benefiting from the state climate policies, Californian cities are by far ahead of the rest of the nation in terms of both quantity and quality of local adaptation plans. The state fosters many opportunities for collaboration and peer-learning through state-wide networks and platforms, such as Cal-Adapt and ILG (Institute for Local Government, 2021) leading to more coordinated planning efforts. As a result, plans of Californian cities use comparable metrics, data, and tools, and demonstrate awareness of climate adaptation plans of other municipalities across the state (City of Laguna Woods City Council, 2014; City of Santa Cruz Climate Action Program, 2018; Town of Corte Madera, 2021; Harris \& Associates, 2021).

Interpretation of these preliminary findings requires deeper analysis of cultural, environmental, demographic, social, and economic factors. Many small municipalities have distinctive and sometimes overlapping niche functions, such as coastal vacation towns (Punta Gorda, FL, Sarasota, FL, Santa Cruz, CA, Salem, MA, Marshfield, MA, Tybee Island, GA, North Kingston, RI, Georgetown, ME), popular active lifestyle and arts destinations (Boulder, CO, Flagstaff, AZ, Taos, NM, ), retirement communities (Laguna Woods, CA, Corte Madera, CA, Sarasota, FL, Punta Gorda, FL, Flagstaff, AZ ), college towns (Santa Cruz, CA, Marquette, lowa City, Thompkins County, Boulder, CO, Albany, NY), etc. Many of these small cities have a great reputation of exceptional quality of life (Boulder, CO, Santa Cruz, CA, Watsonville, CA, Flagstaff, AZ) and some are among the most expensive to live with the median household income and house value significantly higher that their states averages. Although some of these cities are very wealthy, they harbor distinctive pockets of extremely vulnerable populations and sharp socioeconomic contrasts.

Compared to large cities, they have more distinctive vulnerable groups. For example, cities with high rates of populations living below poverty line, such as Albany and Santa Cruz, articulate concerns about low income residents in their plans (New York State Department of State, 2013, City of Santa Cruz Climate Action Program, 2018). Communities with large retired populations, such as Laguna Woods, CA (City of Laguna Woods City Council, 2014) and Corte Madera, CA(Town of Corte Madera, 2021) are

Page 10/19 
especially concerned with sensitivities of the elderly and people with limited mobility but also other vulnerable groups, e.g. people working outdoors in farming communities. Small island communities, such as Georgetown, ME and Tybee Island, GA are already under extremely high stress due to sea-level rise and are particularly concerned with vulnerability of coastal infrastructure and seasonal population migration (Georgetown Conservation Commission, 2015; Evans, Gambill, \& McDowell, 2013). More effective articulation of specific goals relevant for each community would be possible only with deeper analysis of their unique vulnerability profiles, truly inclusive of all groups of stakeholders. And this would require development of comprehensive state-wide and national standards for climate adaptation planning, creating policies to ecourage climate adaptation planning nation-wide, and providing adequate resources for local governments.

This research is still at its nascent stage and has several limitations. The sample of case studies is quite small because very few small municipalities in the United States have developed a climate adaptation plan to date. 23 plans discussed here are climate adaptation champions and not representative of the state of adaptation planning in other small cities and counties. Many of these communities, but not all, tend to have more abundant financial and intellectual resources and more progressive agendas, benefiting from collaboration with local universities and long histories of civic engagement. Factors, such as population age, income, occupation, ethnic and racial diversity, education attainment, and political orientation do influence adaptation priorities and their in-depth quantitative analysis could provide more insights. But the number of small municipalities with adaptation plans is still too limited to generate a sufficiently robust statistical pool to explore the role of these factors. Information examined here is derived from the climate adaptation plans and auxiliary documents, and might be missing many nuances that could be captured though direct observations of the planning process, resident surveys and interviews. More detailed field research and long-term monitoring of participatory planning and plan implementation are necessary to gain more complete information. Despite these limitations, this research is among the very first studies to offer conceptual and methodological approach to examine connections between vulnerability, inclusion, and consideration of equity in adaptation planning strategies. It offers important insights and data, setting a foundation for future national and international assessments of local climate adaptation plans.

\section{Conclusion}

Climate adaptation planning is still an emerging planning field and its importance is likely to increase in the future years as our society is experiencing more and more effects of climate change. Urban poor, people of color, immigrants, and other marginalized populations are disproportionally affected by impacts of climate change and extreme events already, and their vulnerability is likely to increase unless equitable adaptation measures are put in place by municipalities. This is one of the first studies exploring connections between diversity, equity, and inclusion in climate adaptation planning at a local scale. In the absence of national climate adaptation policies, the majority of cities, towns, and counties in the United States still have no climate adaptation plans. Even large high-impact cities use numerous strategies with no implementation guidelines to assure their compatibility for long-term monitoring and coordination (Woodruff \& Stults, 2016) but this is especially challenging for smaller municipalities, who lack adequate resources, guidance, and motivation (Lioubimtseva and da Cunha, 2020). The handful of local adaptation plans of small municipalities examined in study are pioneers providing useful lessons to the rest of the country.

State climate adaptation policies, like in California, are still rarely available but would be crucial in supporting local adaptation planning efforts nationwide, as is support from academia. However, according to the GCC AC portal (2021), only 17 states have finalized their state-led climate adaptation plans and 5 others have other state planning activities on the way, with the rest of the country remaining largely inactive. As a result, the share of cities with climate adaptation plans in the U.S. is still substantially lower compared to many other developed countries, e.g. United Kingdom, European Union members, Australia, and New Zealand. There is a clear urgent need for nationwide climate adaptation policies, guidelines, standards, and incentives for state and local governments to get on board.

Two of our three hypotheses have proven to be true and one false. We found no correlation between the inclusion of stakeholders and consideration of sensitivity and adaptive capacity in vulnerability assessment. Vulnerability assessment is a technical process and involves analysis of climate change trends and scenarios, environmental, social, and economic data.

Page $11 / 19$ 
While variety of methodological guidelines are available to local goverments (ICLEl Local Governments for Sustainability, 2019; California Natural Resources Agency and the Governor's Office of Planning and Research, 2021; Model Forestry Policy Program, 2021), few participants, even if invited, can competently contribute to assessment protocols, due to their technical complexity. As a result, many municipalities delegate vulnerability assessment to external experts, such as private firms or university partners. Even with broad coalitions of stakeholders being involved in designing local climate adaptation plan, the conceptual framework and metrics of vulnerability and its indicators are decided by small number of experts and the odds of community involvement in the choice of guidelines are very low.

Yet, this data analysis reveals very significant correlation between the inclusion of diverse stakeholders and higher considerations of equity in climate adaptation plans. An even stronger correlation is apparent between the consideration of socioeconomic dimensions of community's perceived vulnerability, such as sensitivity and adaptive capacity, and consideration of equity in the proposed adaptation strategies in the plans. Municipalities, who examine their vulnerability beyond physical exposure to climate impacts and consider demographic, social, and economic characteristic of their populations, appear to be much more attentive to social equity and offer specific measures focusing on vulnerable groups. This finding is important and should be further examined as a potentially crucial prerequisite for equitable adaptation planning. All underlying factors of this relationship are not fully explained but have been noted in other city-scale studies (Rivas et al., 2021; Lioubimtseva \& da Cunha, 2022). Do communities, equipped with more complete understanding of vulnerability, pay more attention to equity or, possibly, it is the attention to equity, that promotes critical thinking and encourages municipalities to choose more complete vulnerability assessment frameworks? The key lesson from this finding, however, is that in order to address equity in adaptation measures, communities must first recognize problems of inequity and injustice in their vulnerability assessments. As the baseline for adaptation planning, vulnerability assessment has little value, unless it identifies the already existing inequalities and struggles of vulnerable populations. Unless all participants' voices are heard, it is impossible to say whose challenges are represented, how they are conveyed, who benefits from the process, and if participatory planning is equitable and beneficial for all.

\section{Declarations}

Acknowledgements: I would like to thank Professor Charlotte da Cunha of the University of Versailles for fruitful collaboration on methodological frameworks of monitoring local climate adaptation plans discussed in our joint papers cited here. I also want to thank all local planning department officials, who kindly responded to my inquiries about availability of climate adaptation planning documents of their cities and counties. I am also grateful to Grand Valley State University Libraries Open Access Publishing Support Fund for covering the cost of this publication.

Data availability statement: The dataset of climate adaptation plans generated and analyzed duringthis study is fully referenced in table 1. All 23 climate adaptation plans examined here are publicly available on official websites of their respectivemunicipalities. Quantitative ratings of all assessment criteria of the plans are summarized in figures 3-6 and are available from the corresponding author on reasonable request.

\section{References}

1. AECF. (2021, October 16). The Annie E. Casey Foundation. Retrieved from Equity vs. Equality and Other Racial Justice Definitions: https://www.aecf.org/blog/racial-justice-definitions? gclid=CjwKCAjw8KmLBhB8EiwAQbqNoHLOr04pzkQfSOyPGFt0r5_J3Ksk1JgEG84EQFCvCEiFp6CC4QvmBoCBAOQAvD_BwE

2. Agyeman, J., Bullard, R., \& Evans, B. E. (2003). Just sustainabilities: Development in an unequal world. Cambridge, MA: MIT Press.

3. Andersson, E., J, L., S, B., T, M., D, H., J, K., . . F, B. (2019). nabling Green and Blue Infrastructure to Improve Contributions to Human Well-Being and Equity in Urban Systems. Bioscience, 69(7), 566-574. doi:10.1093/biosci/biz058

4. Anguelovski, I., Shi, L., Chu, E., Gallagher, D., Goh, K., Lamb, Z., .. Teicher, H. (2016). Equity Impacts of Urban Land Use Planning for Climate Adaptation: Critical Perspectives from the Global North and South. Journal of Planning Education and

Page $12 / 19$ 
Research, 36(3), 333-348. doi:https://doi.org/10.1177/0739456X16645166

5. Araos, M., Berrang-Ford, L., Ford, J. D., Austin, S. E., Biesbroek, R., \& Lesnikowski, A. (2016). Climate adaptation planning in large cities: A ystematic global assessment. Environmental Science and Policy, 375-382. doi:doi:

10.1016/j.envsci.2016.06.009.

6. Beever III, J., Gray, W., Trescott, D., Cobb, D., Utley, J., \& Hutchinson, D. (2009). City of Punta Gorda Adaptation Plan. Fort Myers, FL: Southwest Florida Regional Planning Council, Charlotte Harbor National Estuary Program.

7. Bierbaum, R., Smith, J., Lee, A., Blair, M., Carter, L., Chapin, F., .. Verduzco, L. (2013). A comprehensive review of climate adaptation in the United States: more than before, but less than needed. Mitigation and Adaption Strategies for Global Change, 18, 361-406. doi: https://doi.org/10.007/s11027-012-9423-1

8. Brown, A. G. (2011). Managing Adaptation: Linking Theory and Practice. Oxford, UK: School of Geography and the Environment, University of Oxford. Retrieved from www.ukcip.org.uk/wp-content/PDFs/UKCIP_Managing_adaptation.pdf.

9. Bulkeley, H., Carmin, J., Castan Broto, V., Edwards, G. A., \& Fuller, S. (2013). Climate justice and global cities : mapping the emerging discourses. Global Environmental Change, 23(5), 914-925. doi:https://doi.org/10.1016/j.gloenvcha.2013.05.010

10. California Energy Commission. (2021). Exploring California's Climate Change Research. Retrieved from Cal-Adapt: Exploring California's Climate Change Research

11. California Environmental Protection Agency. (2021, 10 27). California Environmental Protection Agency. Retrieved from California Environmental Protection Agency: https://calepa.ca.gov/

12. California Governor's Office of Emergency Services. (2020). California Adaptation PLanning Guide. Sacramento, CA: Governor's Office of Emergency Services.

13. California Natural Resources Agency and the Governor's Office of Planning and Research. (2021). 2021 California Climate Adaptation Strategy. Sacramento: State of California. Retrieved 10 26, 2021, from

https://resources.ca.gov/Initiatives/Building-Climate-Resilience/2021-State-Adaptation-Strategy-Update

14. Chase, J. H., Cooper, J. G., Fitzgerald, R. E., Lima, F. A., Miller, S. R., \& and Pignatelli, T. M. (2012). Climate Change Adaptation Chapter: Marshfield, Massachusetts. UMass Amherst Regional Planning Studio. Amherst, MA: ScholarWorks@UMass Amherst. Retrieved from https://scholarworks.umass.edu/larp_grad_research/23/

15. City of Chula Vista. (2011). Climate Adaptation Strategies Final Implementation Plans. Chula Vista, CA: City of Chula Vista.

16. City of Flagstaff. (2012). City of Flagstaff Resiliency and Preparedness Study. Flafstaff, AZ: City of Flagstaff.

17. City of Flagstaff. (2018). Flagstaff Climate Action and Adaptation PLan. Flagstaff, 2018: City of Flagstaff.

18. City of lowa City. (2018). Iowa City Climate Action and Adaptation Plan. lowa City, IA: City of lowa City.

19. City of Keene. (2007). Adapting to Climate Change: Planning a Climate Resilient Community. Keene, NH: City of Keene \& ICLEI Local Governments for Sustainability.

20. City of Keene. (2010). Keene, NH Climate Adaptation Action Plan Final Report. Keene, NH: City of Keene \& ICLEl Local Governments for Sustainability.

21. City of Laguna Woods City Council. (2014). City of Laguna Woods Climate Adaptation PLan. Laguna Woods, CA: City of Laguna Woods.

22. City of Salem Department of Planning \& Community Development. (2014). Ready for Tomorrow: The City of Salem Climate Change Vulnerability Assessment and Adaptation Plan. Salem, MA: City of Salem.

23. City of Santa Cruz. (2011). City of Santa Cruz Climate Adaptation Plan. Santa Cruz, CA: City of Santa Cruz.

24. City of Santa Cruz Climate Action Program. (2018). City of Santa Cruz 2018 Climate Adaptation Plan Update. Santa Cruz, CA: City of Santa Cruz. Retrieved from https://www.cityofsantacruz.com/government/city-departments/citymanager/climate-action-program/climate-adaptation-planning-copy

25. City of Sarasota. (2016). City of Sarasota Climate Change Vulnerability and Adaptation Plan. Technical Memo. Sarasota, FL: City of Sarasota.

26. City of Sarasota. (2017). City of Sarasota Climate Adaptation PLan. Final Report. Sarasota, FL: City of Sarasota. 
27. da Cunha, C., \& Lioubimtseva, E. (2021). Metadata for climate change adaptation plans of small and mid-size French and American cities. Data Brief, 106981. doi:doi: 10.1016/j.dib.2021.106981

28. Evans, J., Gambill, J., \& McDowell, R. (2013). Tybee Island Sea Level Rise Adaptation Plan. Final Report. Tybee Island, GA: National Sea Grant College Program.

29. Foster, M., Williams, R., Thaler, T., \& Griffith, G. (2010). Forest and Water Climate Adaptation: A Plan for Taos County, New Mexico. Sagle, ID: Model Forest Policy Program.

30. Georgetown Climate Center. (2021, 10 27). Adaptation Clearinghouse. Retrieved from Adaptation Clearinghouse: https://www.adaptationclearinghouse.org/

31. Georgetown Conservation Commission. (2015). Climate Change Adaptation Report: Georgetown, Maine. A special publication by the Georgetown Conservation Commission. Georgetown, ME: Georgetown Conservation Commission.

32. Geospatial Innovation Facility at University of California. (2021, 10 27). Cal-Adapt. Retrieved from Cal-Adapt: https://caladapt.org/

33. Harris \& Associates. (2021). City of Watsonville Climate Action and Adaptation Plan. Watsonville, CA: City of Watsonville Public Works \& Utilities.

34. Holland, B. (2017). Procedural justice in local climate adaptation: political capabilities and transformational change. Environmental Politics, 26(3), 391-412. doi:doi: 10.1080/09644016.2017.1287625.

35. Howe, P. D. (n.d.). The participatory vulnerability scoping diagram - deliberative risk ranking for community water systems." . Annals of the Association of American Geographers, 2(103), 343-352. doi:doi: 10.1080/00045608.2013.754673.

36. Hügel, S., \& Davis, A. R. (2020). Public participation, engagement, and climate change adaptation: A review of the research literature. WIREs Climate Change, 11(4). doi:doi: doi:10.1002/wcc.645

37. ICLEI Local Governments for Sustainability. (2019). Changing Climate, Changing Communities Guide and Workbook for Municipal Climate Adaptation. Toronto, ON: ICLEl-Canada. Retrieved October 30 2021, from https://icleicanada.org/wpcontent/uploads/2019/07/Guide.pdf

38. Institute for Local Government. (2021, 10 26). Climate Adaptation and Resilience. Retrieved from Institute for Local Government: https://www.ca-ilg.org/

39. International Association for Public Participation. (2018). IAP2 Spectrum of Public Participation. Retrieved 2021, from International Association for Public Participation:

https://cdn.ymaws.com/www.iap2.org/resource/resmgr/pillars/Spectrum_8.5x11_Print.pdf

40. International Housing Coalition. (2011). Adapting to Climate Change: Cities and the Urban Poor. Washington, DC: International Housing Coalition.

41. IPCC. (2007). Climate Change 2007: Impacts, Adaptation and Vulnerability. Contribution of Working Group II to the Fourth Assessment Report of the Intergovernmental Panel on Climate Change. Cambridge, UK: Cambridge University Press.

42. IPCC. (2012). Managing the Risks of Extreme Events and Disasters to Advance Climate Change Adaptation. Cambridge, UK: Cambridge University Press.

43. IPCC WGII. (2014). Climate Change 2014: Impacts, Adaptation, and Vulnerability, Contribution of Working Group II to the Fifth Assessment Report of the Intergovernmental Panel on Climate Change. IPCC. Retrieved from http://www.ipcc.ch/report/ar5/wg2/

44. King, H., Thaler, T., Griffith, G., Crossett, T., \& Rasker, R. (2013). Forest and Water Climate Adaptation: A Plan for Marquette County, Michigan. Sagle, ID: Model Forest Policy Program.

45. Klipp, J., Thaler, T., Griffith, G., \& Crossett, T. (2011). Climate Adaptation and Mitigation Plan for Alger County, Michigan. Preparing Communities, Forests and Water Resources for a Changing Climate. Sagle, ID: Model Forest Policy Program.

46. Lioubimtseva, E., \& da Cunha, C. (2020). Local climate change adaptation plans in the US and France:Comparison and lessons learned in 2007-2017. Urban Climate, 31, 10577. doi:10.1016/j.uclim.2019.100577

47. Lioubimtseva, E., \& da Cunha, C. (2022). Community Engagement and Equity in Climate Adaptation Planning: Experience of Small- and Mid-Sized Cities in the United States and in France. In B. Peterson, H. Ducros, B. Peterson, \& H. Ducros (Eds.), 
Justice in Climate Action Planning. Springer International Publishing. doi:10.1007/978-3-030-73939-3

48. Michigan State University. (2013). Adapting to Climate Change and Variability. Marquette, Michigan. Marquette, Ml: Michigan State University, City of Marquette, Superior Watershed Partnership and Land Trust.

49. Model Forestry Policy Program. (2021, 10 08). Climate Solutions University. Retrieved from MFPP Climate Solutions University: https://www.mfpp.org/climate-solutions-university-2/

50. Monterroso, A., \& Conde, C. (2015). Exposure to climate and climate change in Mexico. Geomatics, Natural Hazards, and Risks, 6(4), 272-288. doi:https://doi.org/10.1080/19475705.2013.847867

51. New York State Department of State. (2013). Albany Climate Change Vulnerability Assessment and Adaptation Plan. Albany, NY: Mayor's Office of Energy and Sustainability.

52. Northridge, M., \& Freeman, L. (2011). Urban planning and health equity . Journal of Urban Health, 88(3), 582-597. doi:doi: $10.1007 / \mathrm{s} 11524-011-9558-5$

53. Olazabal, M., Gallaraga, I., Ford, J., Sainz, E., \& Lesnikowski, A. (2019). Are local climate adaptation policies credible? A conceptual and operational assessment framework. International Journal of Urban Sustainable Development, 11(3), 277 296. doi:https://doi.org/10.1080/19463138.2019.1583234

54. Polsky, C. R. (2007). Building comparable global change vulnerability assessment: The vulnerability scoping diagram. Global Environmental Change, 17(3), 472-485. doi:doi.org/10.1016/j.gloenvcha.2007.01.005

55. Reckien, D., Lwasa, S., Satterthwaite, D., McEvoy, D., \& Creutzig, F. (2018). Equity, Environmental Justice, and Urban Climate Change. In C. W.-L. Rosenzweig, Climate Change and Cities: Second Assessment Report of the Urban Climate Change Research Network (pp. 173-224). New York: Cambridge University Press.

56. Rhode Island Sea Grant \& University of Rhode Island Coastal Resources Center. (2015). Adaptation to Natural Hazards and Climate Change in North Kingstown, Rhode Island. Providence, RI: Rhode Island Statewide Planning Program.

57. Rivas, S., Hernandez, Y., Urraca, R., \& Barbosa, P. (2021). A comparative analysis to depict underlying attributes that might determine the successful implementation of local adaptation plans. Environmental Science \& Policy, 7, 25-33.

doi:https://doi.org/10.1016/j.envsci.2020.12.002

58. Roberson, Q. M. (2004, June). Disentangling the Meanings of Diversity and Inclusion. Center for Advanced Human Resource Studies/Cornell University Working Paper Series, CAHRS WP 04-05, pp. 2-31. Retrieved from https://www.ilr.cornell.edu/CAHRS

59. Shore, L. M., Randel, A. E., Chung, B. G., Dean, M. A., Holcombe Ehrhart, K., \& Singh, G. (2011). Inclusion and Diversity in Work Groups:. Journal of Management, 37(4), 1262-1289. doi:10.1177/0149206310385943

60. Smit, B., \& Wandel, J. (2006). Adaptation, adaptive capacity and vulnerability. Global Environmental Change, 16, $282-292$. doi:https://doi.org/10.1016/j.gloenvcha.2006.03.008

61. Stratus Consulting. (2012). Boulder County Climate Change. Boulder County, CO: Boulder County .

62. Stults, M., \& Pagach, J. (2011). Preparing for Climate Change in Groton, Connecticut: A Model Process for Communities in the Northeast. Groton, CT: ICLEI-Local Governments for Sustainability and Connecticut Department of Environmental Protection.

63. Superior Watershed Partnership \& Model Forestry Policy Program. (2013). Climate Adaptation Plan for Marquette County, Michigan. Marquette, MI: Superior Watershed Partnership and the Climate Solutions University.

64. Taylor Engineering, I. (2019). City of Punta Gorda Adaptation Plan Update. Punta Gorda, FL: City of Punta Gorda.

65. Thomas, D. S., \& Twyman, C. (2005). Equity and justice in climate change adaptation amongst natural-resource-dependent societies. Global Environmental Change(15), 115-124. doi:doi:10.1016/j.gloenvcha.2004.10.001

66. Tompkinds County Planning Department. (2015). Tompkinds County Comprehensive Plan. PLanning for Our Future: Adaptation Chapter.

67. Town of Corte Madera. (2021). Town of Corte Madera Climate Adaptation Assessment: A Roadmap to Resilience. Corte Madera, CA: Town of Corte Madera. Retrieved from cortemaderaadapts.org 
68. Town of Corte Madera. (2021). Town of Corte Madera Climate Adaptation Assessment: A Roadmap to Resilience. Corte Madera, CA: Town of Corte Madera. Retrieved from https://cortemaderaadapts.org/

69. Uittenbroek, C., Mees, H., Hegger, D., \& Driesses, P. (2019). The design of public participation: who participates, when and how? Insights in climate adaptation planning from the Netherlands. Journal of Environmental Planning and Management, 62(14), 2529-2547. doi:https://doi.org/10.1080/09640568.2019.1569503

70. United Nations. (2021, October 16). UN Sustainable Development Goals. Retrieved from Climate Justice: https://www.un.org/sustainabledevelopment/blog/2019/05/climate-justice/

71. Vogel, J. C. (2016). Climate adaptation. The state of practice in U.S. communities. The Kresge Foundation. Detroit: The Kresge Foundation.

72. Woodruff, S. C. (2018). City membership in climate change adaptation networks. Environmental Science \& Policy, 60-68. doi: doi: https://doi.org/10.1016/j.envsci.2018.03.002.

73. Woodruff, S. C., \& Stults, M. (2016). Numerous strategies but limited implementation guidance in US local adaptation plans. Nature Climate Change, 6, 796. doi:10.1038/nclimate3012

\section{Figures}

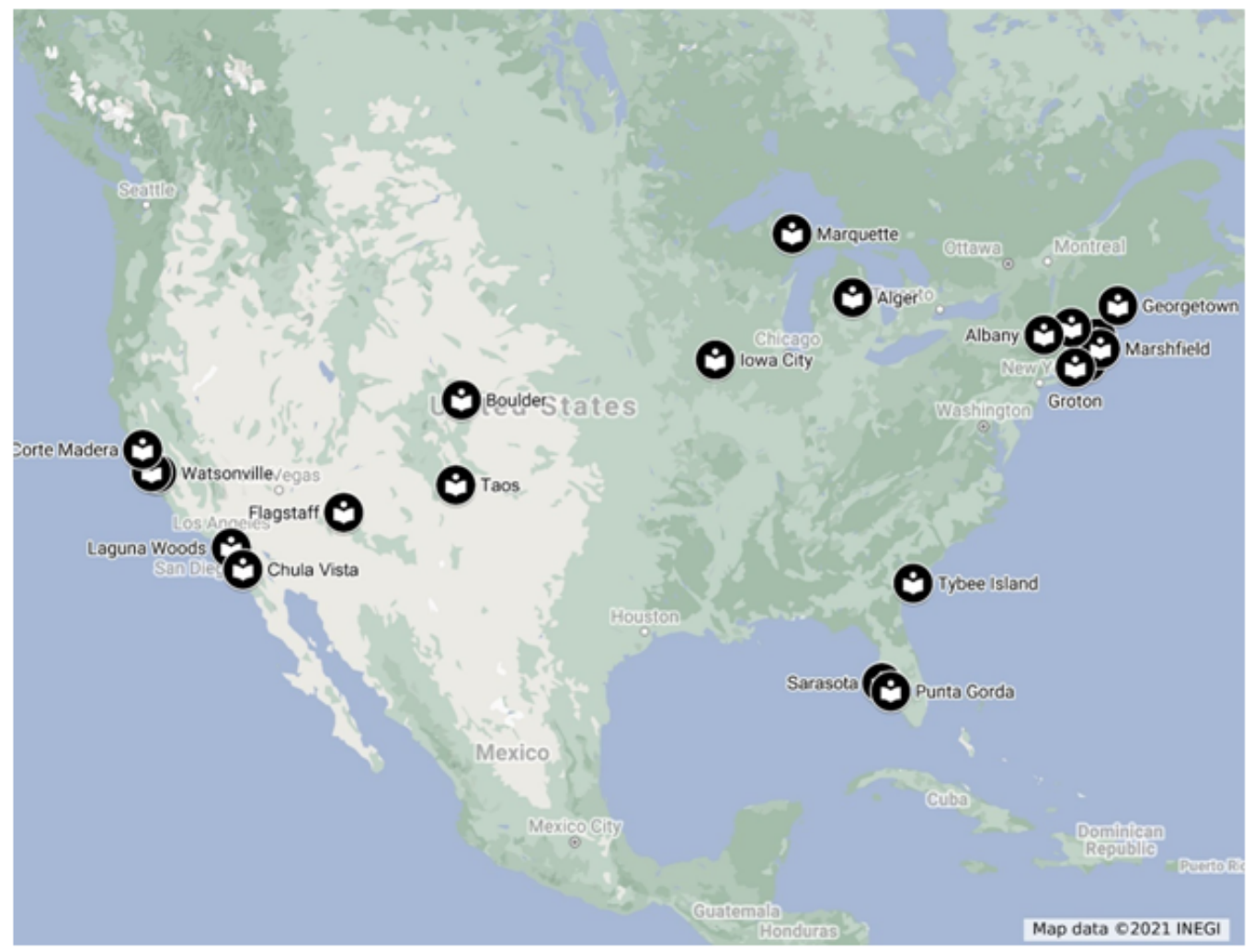

\section{Figure 1}

Climate adaptation plans (created by the author with Google Maps) 


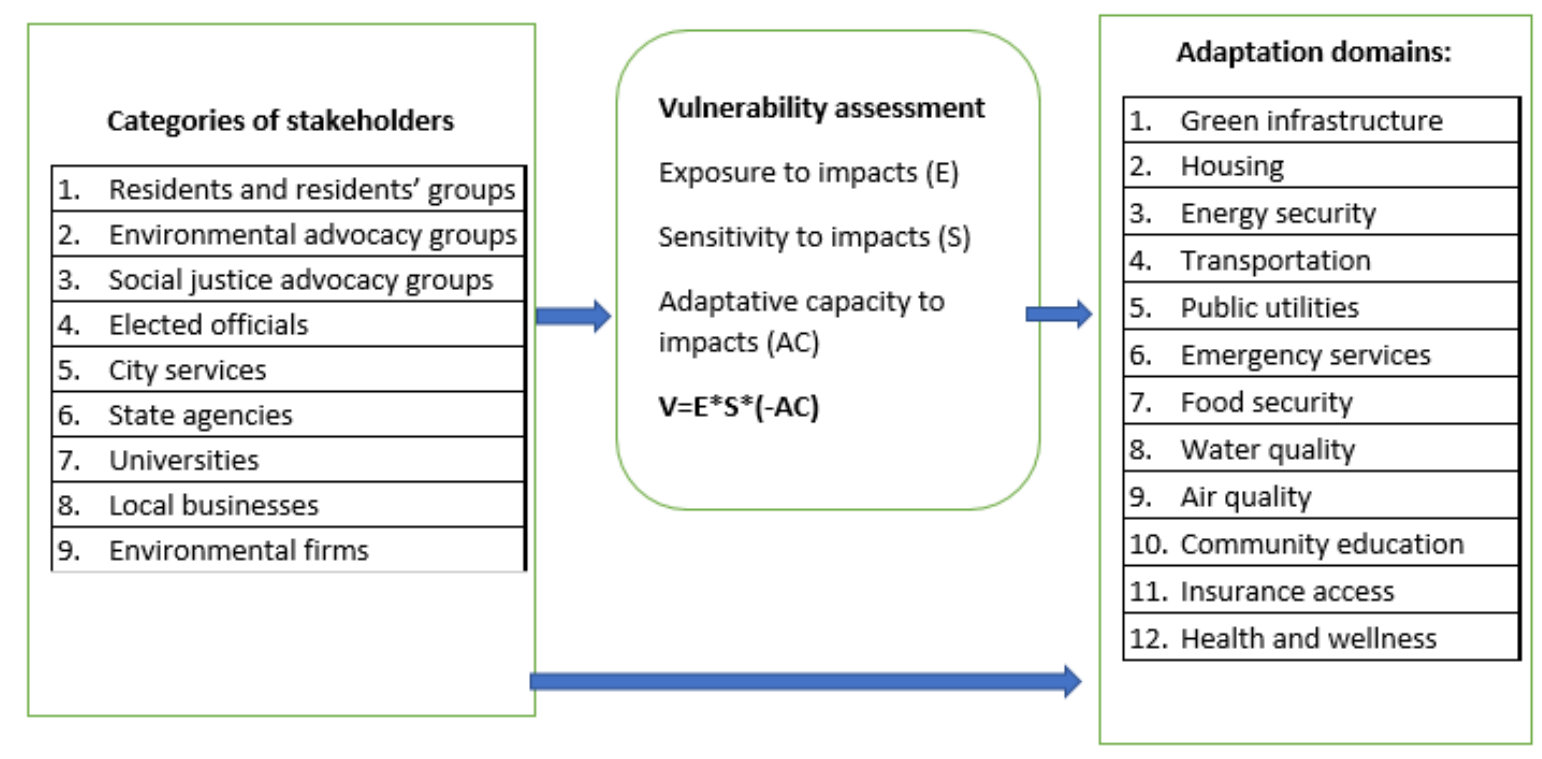

Figure 2

Conceptual framework for the analysis of climate adaptation plans (adapted from Lioubimtseva and da Cunha, 2022).

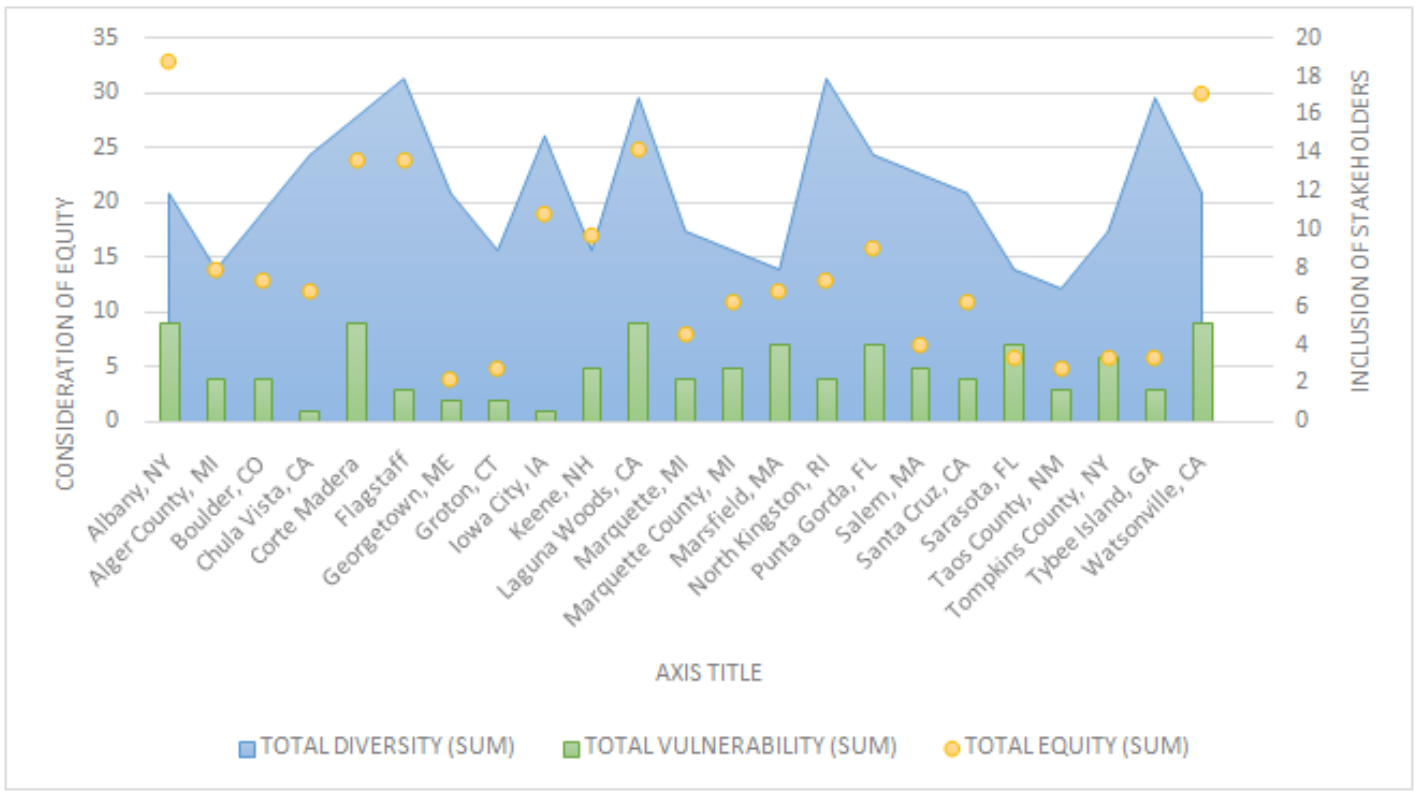

\section{Figure 3}

Correlations of consideration of equity with diversity of stakeholders and perceived community vulnerability. 


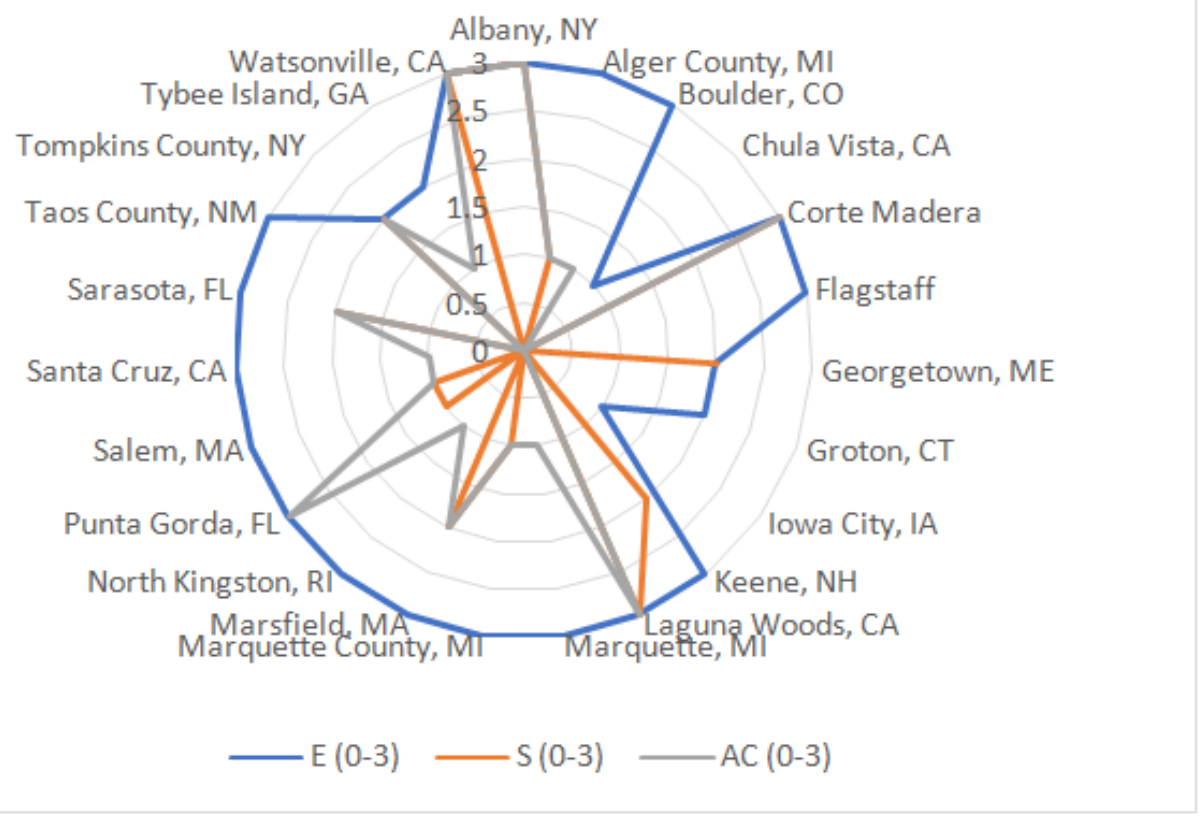

\section{Figure 4}

Perceived Vulnerability based on assessment of exposure, sensitivity, and adaptive capacity considered in the local plans

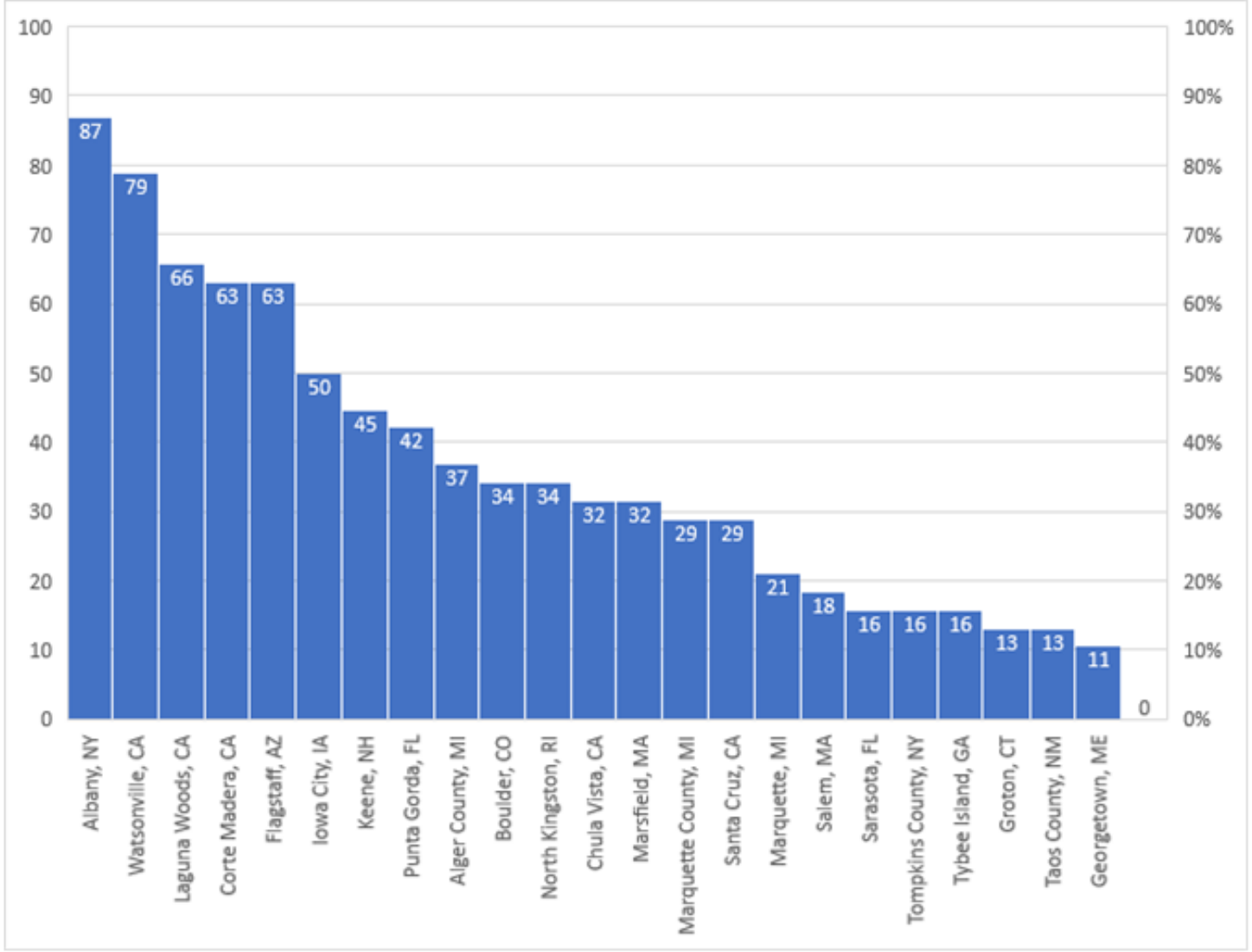

\section{Figure 5}

Inclusion of stakeholders' categories in development of climate adaptation plans 


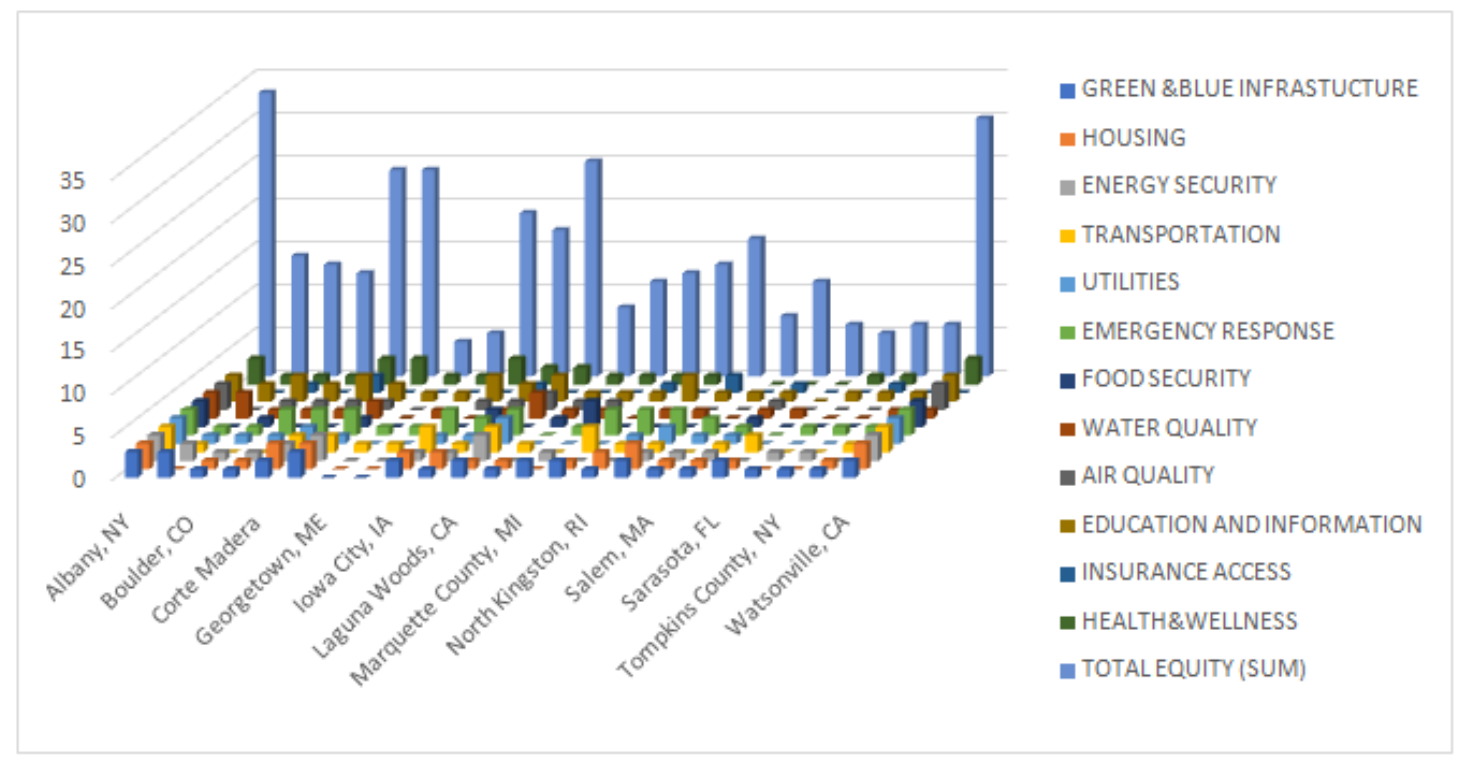

\section{Figure 6}

Consideration of equity in climate adaptation domains 